In cooperation with the Wisconsin Department of Transportation and the Marathon County and Jefferson County Highway Departments

\title{
Bridge Scour Monitoring Methods at Three Sites in Wisconsin
}

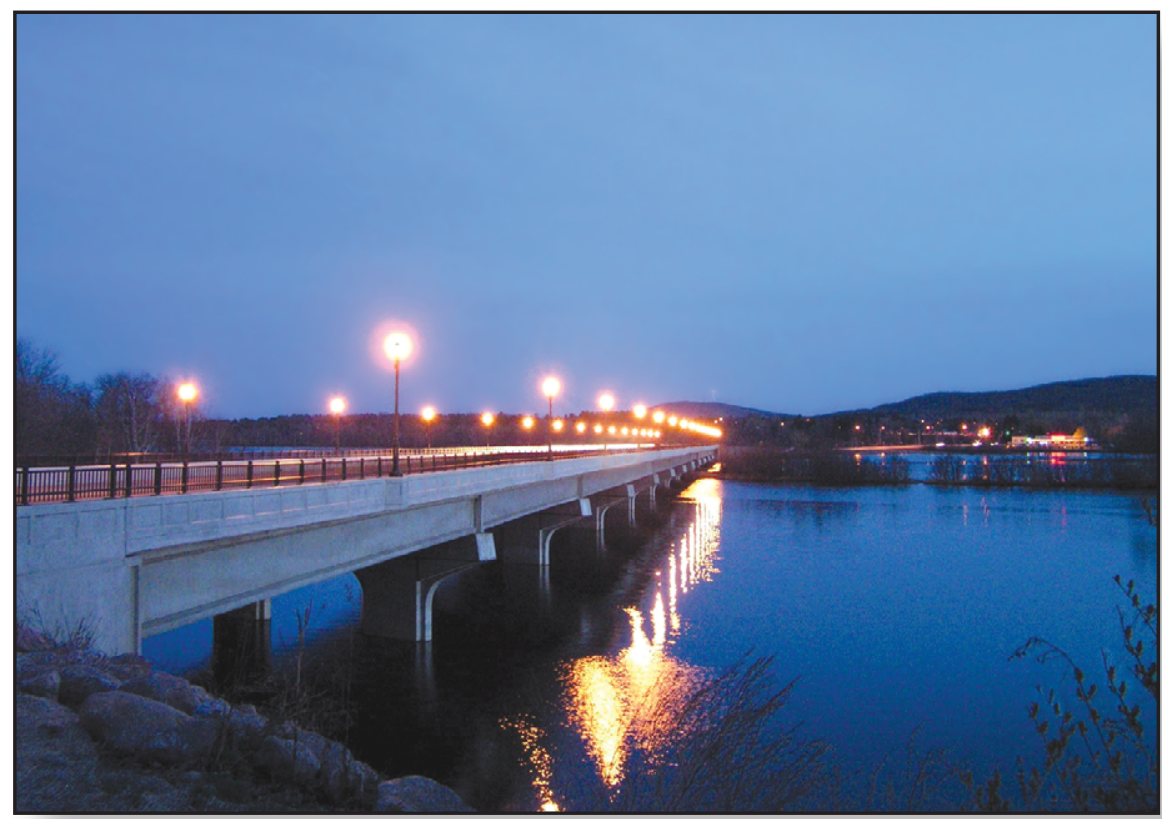

Open-File Report 2005-1374 


\section{Bridge Scour Monitoring Methods at Three Sites in Wisconsin}

By John F. Walker and Peter E. Hughes

In cooperation with the Wisconsin Department of Transportation and the Marathon County and Jefferson County Highway Departments

Open-File Report 2005-1374 


\section{U.S. Department of the Interior \\ Gale A. Norton, Secretary}

\section{U.S. Geological Survey \\ P. Patrick Leahy, Acting Director}

U.S. Geological Survey, Reston, Virginia: 2005

For product and ordering information:

World Wide Web: http://www.usgs.gov/pubprod

Telephone: 1-888-ASK-USGS

For more information on the USGS--the Federal source for science about the Earth, its natural and living resources, natural hazards, and the environment:

World Wide Web: http://www.usgs.gov

Telephone: 1-888-ASK-USGS

Any use of trade, product, or firm names is for descriptive purposes only and does not imply endorsement by the U.S. Government.

Although this report is in the public domain, permission must be secured from the individual copyright owners to reproduce any copyrighted materials contained within this report. 


\section{Contents}

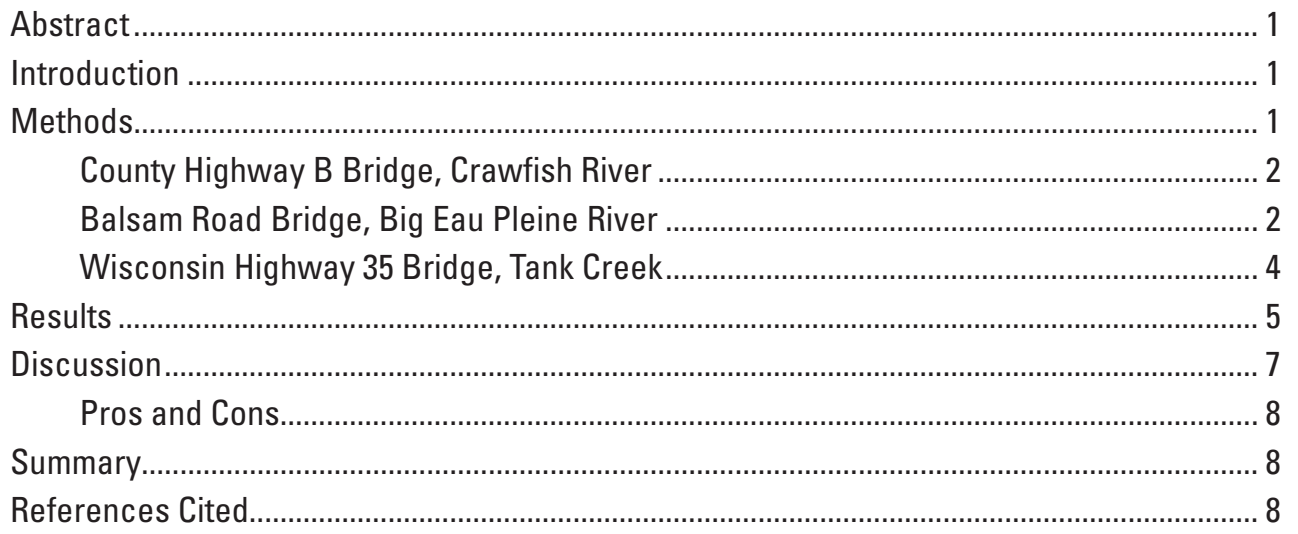

\section{Figures}

1. Map showing the location of the three sites with bridge scour monitoring ............. 2

2. Photograph showing wire-weight gages on the County $B$ bridge over the Crawfish River in Jefferson County, Wisconsin. ......................................................... 3

3. Photograph showing the Balsam Road bridge over the Big Eau Pleine River in Marathon County, Wisconsin............................................................................. 3

4. Photograph showing the Wisconsin Highway 35 bridge over Tank Creek in Trempealeau County, Wisconsin.............................................................................. 4

5. Photograph showing the transducer mount on the upstream edge of the pier, Tank Creek installation .................................................................................... 4

6. Graph showing scour measurements at the County B bridge over the Crawfish River...

7. Graph showing continuous scour record from the upstream transducer at the Balsam Road bridge over the Big Eau Pleine River for (A) a small storm in April, 1999 and (B) several flow events in July, 1999

8. Graph showing continuous scour measurements from the upstream transducer at the Wisconsin Highway 35 bridge over Tank Creek 


\section{Conversion Factors and Abbreviated Units of Measure}

\begin{tabular}{lll}
\hline \multicolumn{1}{c}{ Multiply } & \multicolumn{1}{c}{ By } & \multicolumn{1}{c}{ To obtain } \\
\hline & \multicolumn{1}{c}{ Length } \\
\hline inch (in.) & 2.54 & centimeter $(\mathrm{cm})$ \\
foot (ft) & 0.3048 & meter $(\mathrm{m})$ \\
mile (mi) & 1.609 & kilometer $(\mathrm{km})$ \\
\hline \multicolumn{3}{c}{ Flow rate } \\
\hline cubic foot per second $\left(\mathrm{ft}^{3} / \mathrm{s}\right)$ & 0.02832 & \\
\hline \multicolumn{2}{c}{ Mass } & \\
\hline pound, avoirdupois $(\mathrm{lb})$ & 0.4536 & kilogram $(\mathrm{kg})$ \\
\hline
\end{tabular}




\title{
Bridge Scour Monitoring Methods at Three Sites in Wisconsin
}

\author{
By John F. Walker and Peter E. Hughes
}

\begin{abstract}
Of the nearly 11,500 bridges in Wisconsin, 89 have been assessed with critical scour conditions. The U.S. Geological Survey, in cooperation with the Wisconsin Department of Transportation, the Marathon County Highway Department, and the Jefferson County Highway Department, performed routine monitoring of streambed elevations for three bridges. Two monitoring approaches were employed: (1) manual monitoring using moderately simple equipment, and (2) automated monitoring, using moderately sophisticated electronic equipment. The results from all three sites demonstrate that both techniques can produce reasonable measurements of streambed elevation. The manual technique has a lower annual operating cost, and is useful for cases where documentation of long-term trends is desired. The automated technique has a higher annual operating cost and is useful for real-time monitoring of episodic events with short time durations.
\end{abstract}

\section{Introduction}

There are nearly 11,500 bridges spanning the multitude of waterways in Wisconsin. Most bridge crossings result in a constriction of the natural cross-section of the stream, which can lead to increased velocities during conditions of flooding. In some cases the local flow conditions produce extremely high velocities that can scour the sediment in the streambed. If the local scour conditions are severe enough to expose the foundation of bridge piers or abutments, the results can be catastrophic.

As part of a National Bridge Inventory (NBI) to document the condition of the nation's bridges, the Wisconsin Department of Transportation (WisDOT) has completed an assessment of the bridges in Wisconsin. One of the factors included in the inventory is the potential for excessive scour in the vicinity of the piers and footings relative to the base of the footing. The methods used to assess the scour potential (NBI Item 113) are described in a Federal Highway Administration report (Richardson and Davis, 2001). Values for NBI Item 113 that are 3 or less indicate critical scour conditions. In Wisconsin, 87 bridges inventoried were rated a scour code of 3 (critical scour conditions), and 2 bridges were rated a scour code of 2 (critical scour conditions with evidence of extensive past scour). The scour conditions at 1,583 bridges are unknown.

Scour monitoring can serve as a valuable countermeasure tool that provides WisDOT and County Highway Departments with an essential element for plans of action for bridges with scour-critical conditions or unknown foundations. In November of 1997 the U.S. Geological Survey, in cooperation with the Marathon County Highway Department and WisDOT, began a pilot project to monitor bridge scour at the Balsam Road bridge over the Big Eau Pleine River in Marathon County, Wisconsin. This effort was undertaken as a follow-up to a report describing the scour potential of the bridge (Parsons Brinckerhoff, Quade \& Douglas, Inc., 1997). In April of 2000 the U.S. Geological Survey, in cooperation with WisDOT, began monitoring bridge scour at the Wisconsin Highway 35 bridge over Tank Creek in Trempealeau County, Wisconsin. In October of 2002 the U.S. Geological Survey, in cooperation with the Jefferson County Highway Department, began monitoring bridge scour at the County Highway B bridge over the Crawfish River in Jefferson County, Wisconsin. The purpose of this report is to describe the two monitoring approaches used at the three sites (fig. 1), present selected results, and discuss the pros and cons of the different approaches.

\section{Methods}

Two different data-collection approaches were used at the three sites, in part due to funding restrictions. This section presents a description of the equipment and the datacollection procedures used at each site. In addition, relative 


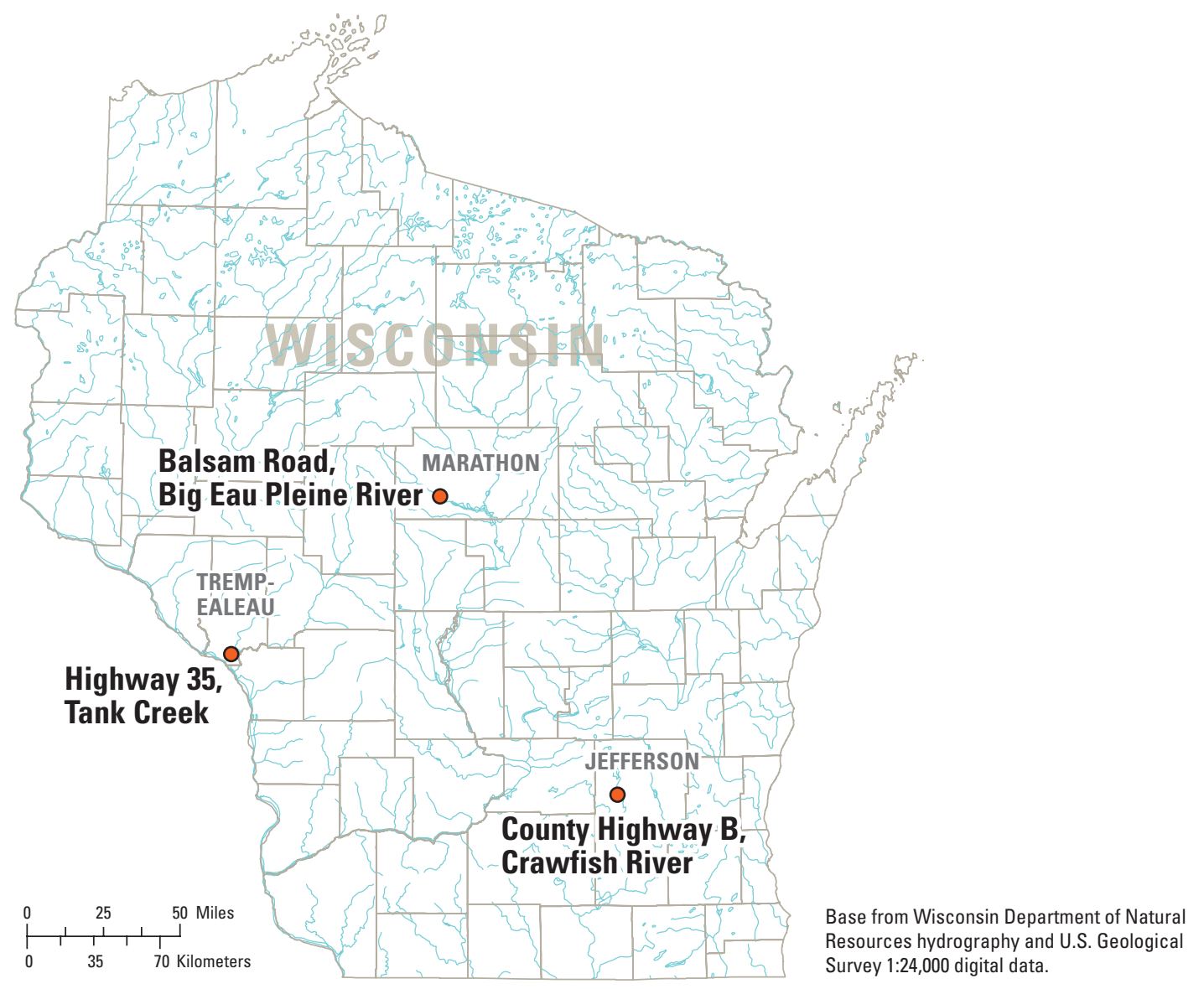

Figure 1. Location of the three sites with bridge scour monitoring.

costs of installation and operation are presented. The three sites are presented in relation to the degree of sophistication of the equipment used to monitor streambed scour.

\section{County Highway B Bridge, Crawfish River}

The County Highway B bridge spans the Crawfish River in Jefferson County. The bridge, which was rebuilt in 2002, consists of three spans supported by two piers that rest on spread concrete footings. The bridge has an overall length of $230 \mathrm{ft}(70 \mathrm{~m})$. The bed material consists of a 10-foot (3-meter) layer of loose gray silt mixed with limited clay and sand over a layer of dense brown fine to coarse sand mixed with some silt. The bridge inventory for this site resulted in an NBI Item 113 code of 8, which represents a stable foundation for calculated or estimated scour conditions.

The equipment installed at the site consists of two manual wire-weight gages, installed on the upstream rail of the bridge (fig. 2) in line with the two piers. The gages contain a calibrated reel which displays the distance from the reel to the weight using a series of counters. The gages are operated by lowering the weight to the water surface and then to the streambed, and the distances from the gage to each surface are recorded on a field form. The gages can be read to within $0.01 \mathrm{ft}(0.3 \mathrm{~cm})$, but the accuracy of distance to the streambed is probably on the order of $0.05 \mathrm{ft}$ $(1.5 \mathrm{~cm})$. The measurement accuracy will depend upon the technique used to drop the weight to the streambed without allowing it to be carried a substantial distance downstream during high-flow conditions. A 10-lb $(4.5 \mathrm{~kg})$ downrigger ball was selected to minimize this problem. Measurements were collected approximately monthly from March through May of 2003, and in May and June of 2004. The cost of the equipment in 2002 was approximately $\$ 3,000$, and the cost of installation and operation for a one-year period was approximately $\$ 3,300$.

\section{Balsam Road Bridge, Big Eau Pleine River}

The Balsam Road bridge spans the Big Eau Pleine River in Marathon County (fig. 3). Currently (2005) the 


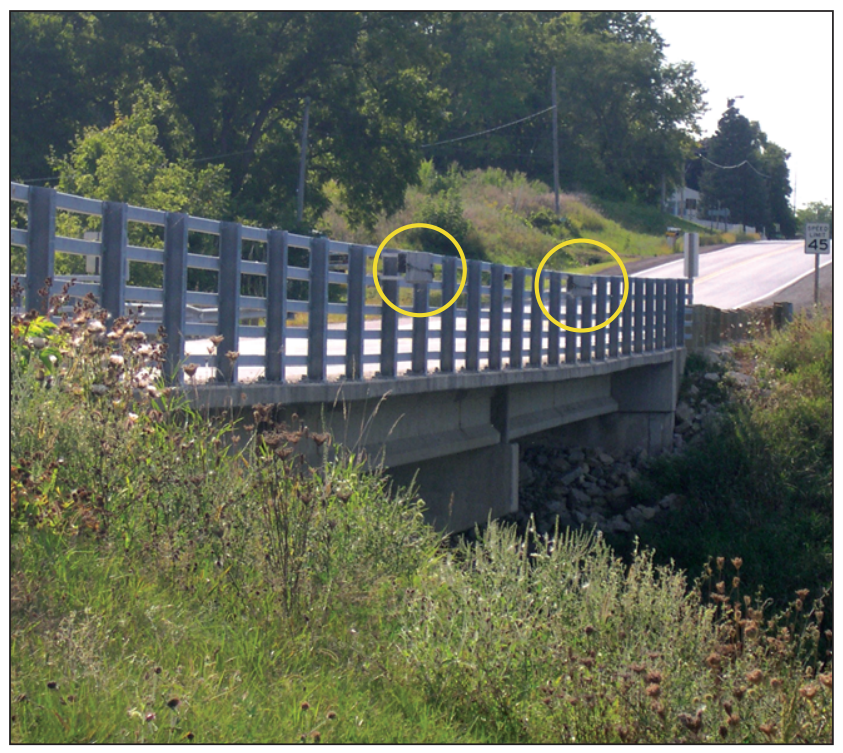

Figure 2. Wire-weight gages (circled) on the County B bridge over the Crawfish River in Jefferson County, Wisconsin.

bridge has been removed, and a new structure is being built. The old bridge, which was built in 1939, consisted of four spans supported by three piers founded on 30-ft (9-m) timber piles which were driven to the point of refusal. The bridge had an overall length of $220 \mathrm{ft}(67.1 \mathrm{~m})$. The bed material consists of a 4-8 foot (1.2-2.4 meter) layer of sand with a varying amount of silt and gravel. Bedrock is about $25 \mathrm{ft}(7.6 \mathrm{~m})$ below the streambed. The bridge inventory for this site resulted in an NBI Item 113 code of 3, which represents an unstable foundation for calculated or estimated scour conditions.

The equipment at the site consisted of two Datasonics PSA-916 sonar transducers, mounted on the upstream and downstream edges of the eastern most bridge pier. Divers from the Marathon County Highway Department found the footing for this pier exposed above the streambed and the evidence of scour was much more pronounced than at the other piers. The transducers were connected to a Campbell Scientific CR10 datalogger, which recorded distance to the streambed at the two locations using a 15-minute recording interval. The stated accuracy of the sonar units is $0.083 \mathrm{ft}(2.5 \mathrm{~cm})$. Data from the Campbell datalogger was transmitted via phone to the office in Middleton, and was made available through the real-time data network (http://wi.waterdata.usgs.gov/nwis/current/?type=scour). The equipment was operated from June of 1998 until September of 2001. The cost of the equipment in 1997 was approximately $\$ 4,800$, the installation cost was approximately $\$ 4,200$, and the annual cost of operation of the equipment was $\$ 4,000$.

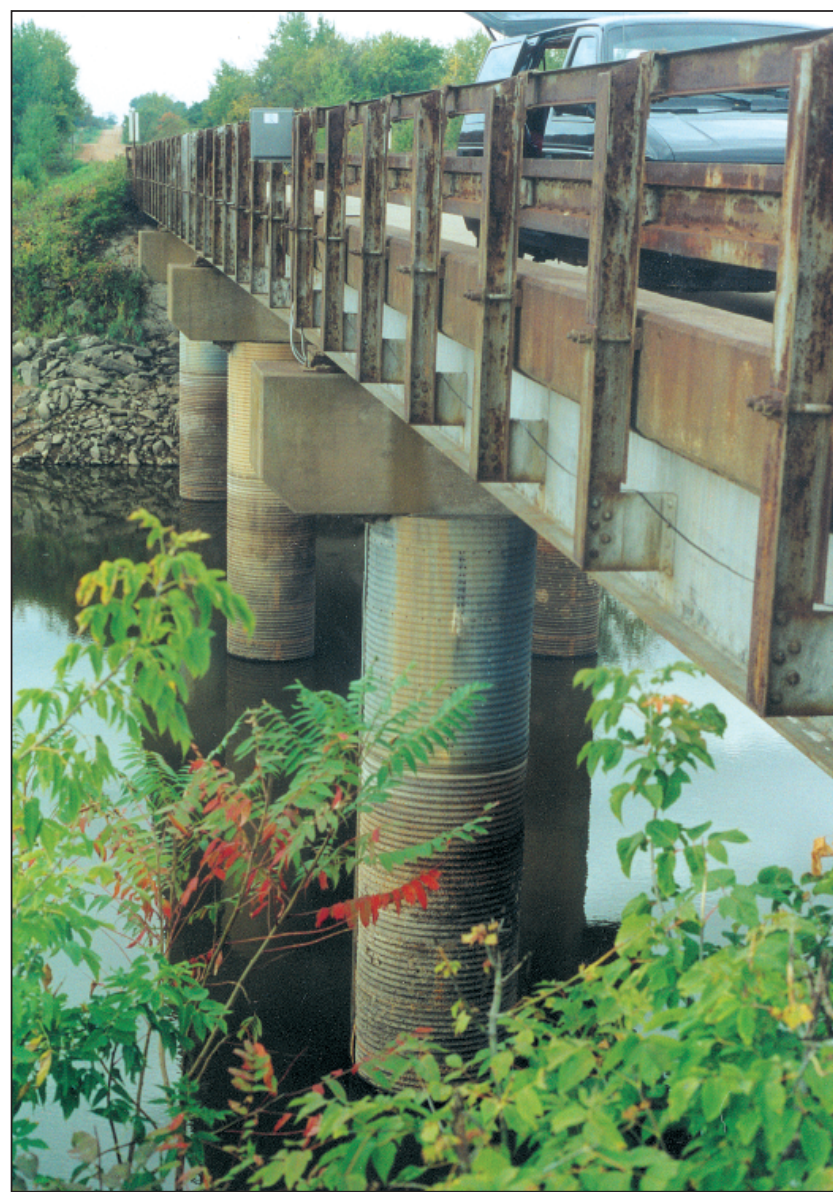

Figure 3. Photograph showing the Balsam Road bridge over the Big Eau Pleine River in Marathon County, Wisconsin.

The transducers were initially mounted using a length of channel iron that was strapped to the surface of the $5 \mathrm{ft}$ $(1.5 \mathrm{~m})$ diameter corrugated steel pier. At the bottom of the channel iron, the transducers were angled to prevent signal reflection from the footing. The upstream mount was damaged during ice flows in the spring of 2000, and a new mount was installed in November 2000 with the assistance of the WisDOT and their reach-all truck. This second mount was damaged during ice flows in the spring of 2002. Because the upstream side of the pier is generally more vulnerable to scour, it is necessary to position the sonar devices in an area susceptible to damage from ice and debris. The cost and difficulty of designing, fabricating, and installing durable mounting systems cannot be understated. The ideal system would protect the transducer and cable from debris damage, hold the transducer in a rigid position, and allow the transducer to be removed for service or repair without undue difficulty or cost.

With the deployment of unattended electronic equipment, periodic check measurements are essential to verify 
the operation of the equipment. Check measurements were made by a local observer and by personnel from the Township of Cleveland approximately monthly during 1998 and semi-annually in 1999 and 2000. USGS personnel made check measurements quarterly between 1999 and 2001. The recorded depth of the scour hole from the transducer data was within $\pm 0.3 \mathrm{ft}( \pm 9 \mathrm{~cm})$ of the field measurement data for the period June 1998 through March 2000. Few check measurements were obtained during actual scour events.

\section{Wisconsin Highway 35 Bridge, Tank Creek}

The Wisconsin Highway 35 bridge spans Tank Creek in Trempealeau County (fig. 4). The bridge, which was built in 1951, consists of 3 spans supported by 2 piers founded on spread footings. The bridge has an overall length of $130 \mathrm{ft}(40 \mathrm{~m})$. During the 1993 floods the footings and some length of the piles were exposed. As a countermeasure, the streambed sediments in the vicinity of the piers and footings were armored with 8-18 in. (20-46 cm) breaker-run rock in an attempt to control the scour at the site. The bridge inventory for this site resulted in an NBI Item 113 code of 3, represents an unstable foundation for calculated or estimated scour conditions.

The equipment at the site consists of a Datasonics PSA-916 sonar transducer, mounted on the upstream edge of the eastern-most bridge pier (fig. 5). WisDOT had indicated that the scour in the past had been more pronounced at this pier. The transducer was connected to

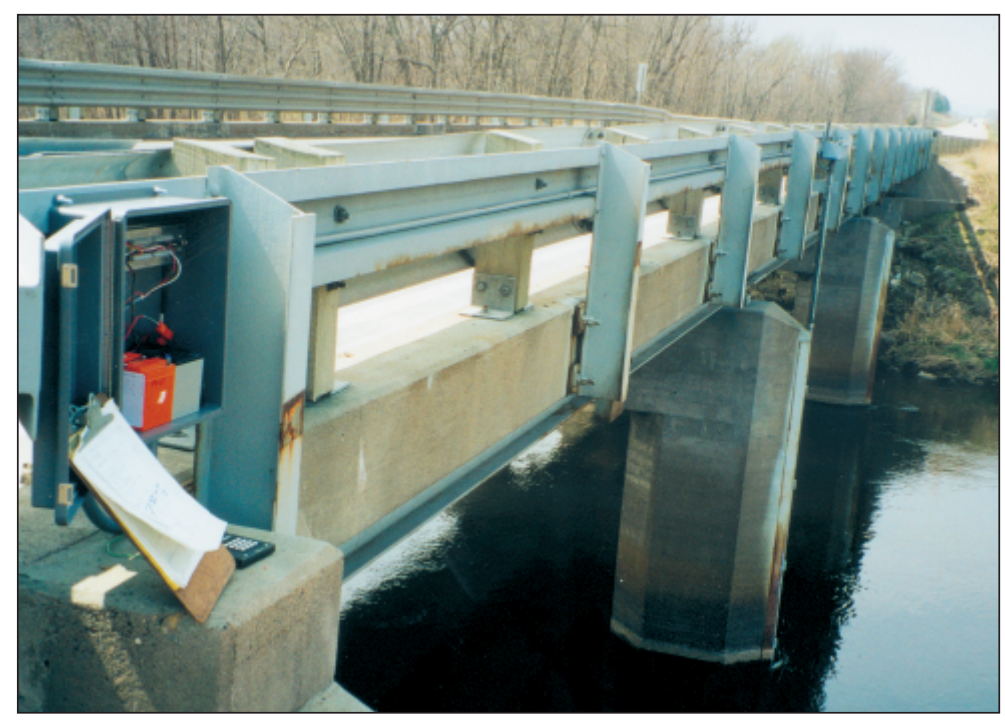

Figure 4. Photograph showing the Wisconsin Highway 35 bridge over Tank Creek in Trempealeau County, Wisconsin. a Campbell Scientific CR10 datalogger, which recorded distance to the streambed using a 15-minute recording interval. In addition to the sonar transducer, a Kellor KPSI Series 760 SDI-12 0-5 psi depth sensor was used to measure the stream stage using the same recording interval. The stated accuracy of the sonar unit is $0.083 \mathrm{ft}(2.5 \mathrm{~cm})$, and the stated accuracy of the stage-sensing equipment is $0.01 \mathrm{ft}(0.3 \mathrm{~cm})$. Data from the Campbell datalogger was transmitted via phone to the office in Middleton, and made available immediately through the real-time data network (http://wi.waterdata.usgs.gov/nwis/current/?type=scour). The equipment began operating in April of 2000 and continues to be active as of this writing (September 2005). The cost of the equipment in 1999 was approximately $\$ 3,400$, and the cost for fabrication of the mounting system and installation was approximately $\$ 6,800$. The annual cost of operation of the equipment was approximately

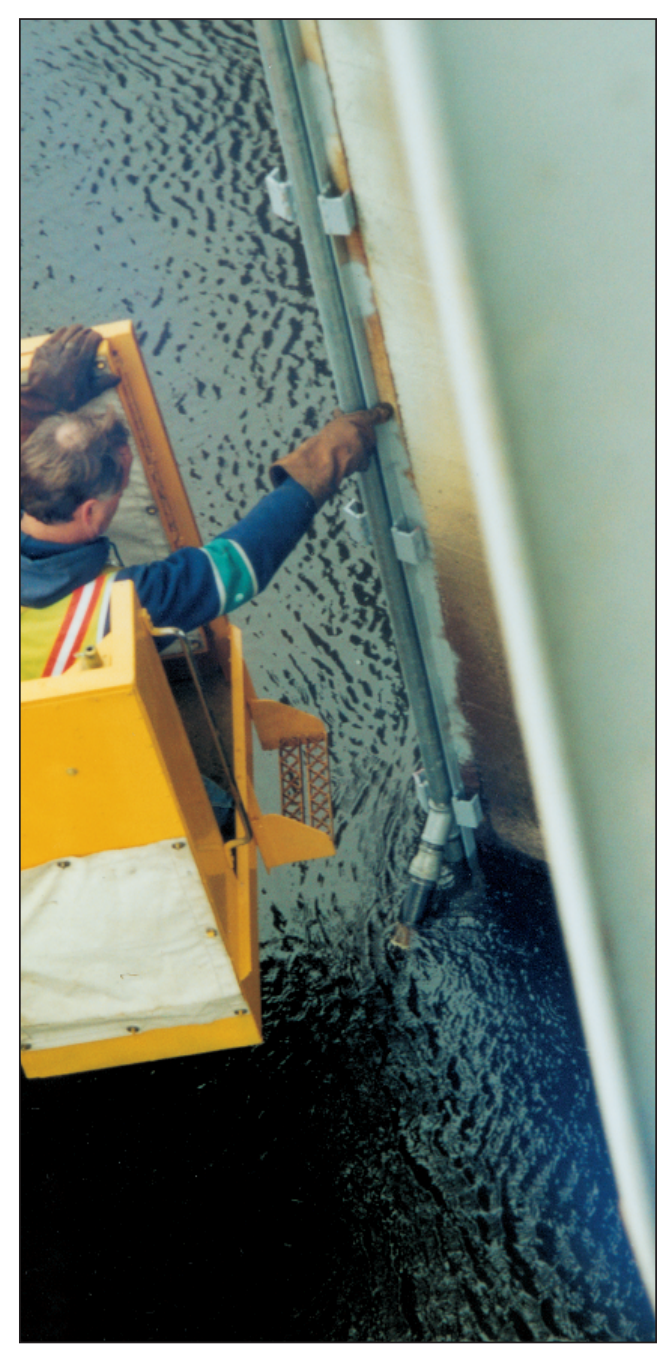

Figure 5. Photograph showing the transducer mount on the upstream edge of the pier, Tank Creek installation. 

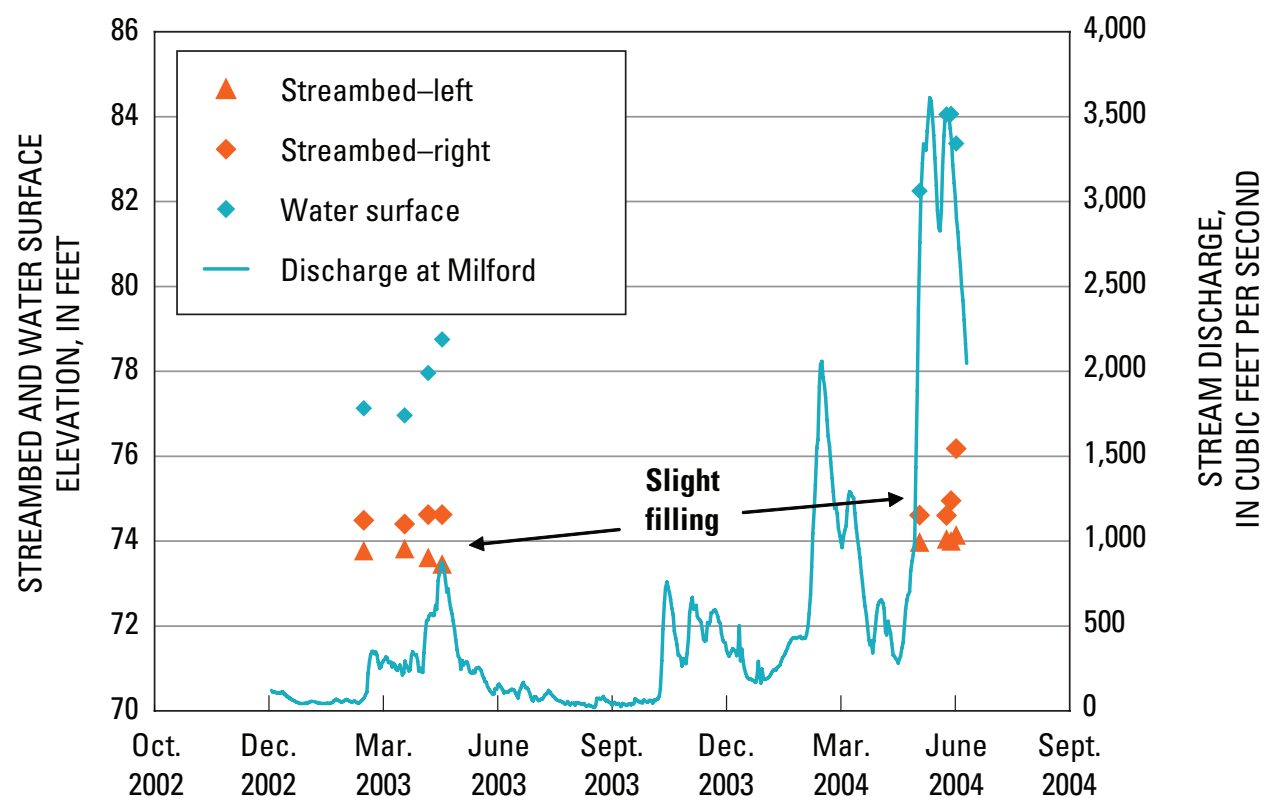

Figure 6. Scour measurements at the County B bridge over the Crawfish River. The discharge hydrograph is from the gage at Milford, $2.2 \mathrm{mi}(3.5 \mathrm{~km})$ upstream of the bridge.

$\$ 4,000$. Items not factored into this cost estimate include the personnel time and equipment charges incurred by WisDOT for providing the reach-all and welding equipment, and Trempealeau County for providing traffic-control vehicles during installation. Installation of the equipment can generally be completed in one day utilizing a pre-built mounting system.

The Tank Creek bridge has wedge-shaped piers with an embedded channel iron at the upstream face. This provided an ideal surface for welding a transducer mounting system that allows the transducer and cable to be protected from debris damage, holds the transducer in position above the streambed, and allows for easy removal for repair. There has been no damage to this system since its installation.

\section{Results}

The results for the monitoring at the County Highway B Bridge over the Crawfish River are presented in figure 6. The discharge from the gage at Milford, located $2.2 \mathrm{mi}$ $(3.5 \mathrm{~km})$ upstream of the bridge, is included for reference as an indication of the magnitude of the flow events during the periodic monitoring. For the monitoring period from March to May of 2003, during conditions of increasing discharge, the streambed was scouring slightly on the left pier, and filling slightly on the right. This pattern indicates variation in local velocities in the vicinity of the piers. For the subsequent monitoring period in May and June of 2004, the streambed was filling in the vicinity of both piers, even though there was a fairly substantial flow event at the Milford gage. Based on frequency analysis using data through the 2000 water year (Walker and Krug, 2003), the event in February 2004 approached the two-year discharge, and the event in March 2004 had a recurrence interval between 5 and 10 years. Insufficient data exist to determine if the streambed is still recovering from the bridge construction activities during the previous year or if the measured streambed aggradation is typical for the experienced flows. Over the entire monitoring period, there has been some slight filling of the channel on the order of $0.5 \mathrm{ft}(0.15 \mathrm{~m})$.

Selected results for the continuous scour monitoring at the Balsam Road bridge over the Big Eau Pleine River are presented in figure 7. Discharge for the gage at Stratford, located $7.7 \mathrm{mi}(12.4 \mathrm{~km})$ upstream of the bridge, is included for reference as an indication of the magnitude of the flow events. The small event depicted in the upper panel (fig. 7a) illustrates classic scour of the streambed during the rising limb of the hydrograph, and subsequent filling during the falling limb. This behavior would be a direct result of variations of velocity in the vicinity of the pier. Note that there is essentially no net change in the streambed elevation as a result of this flow event. The longer period of record depicted in the lower panel (fig. $7 b)$ exhibits a more complicated pattern of association 


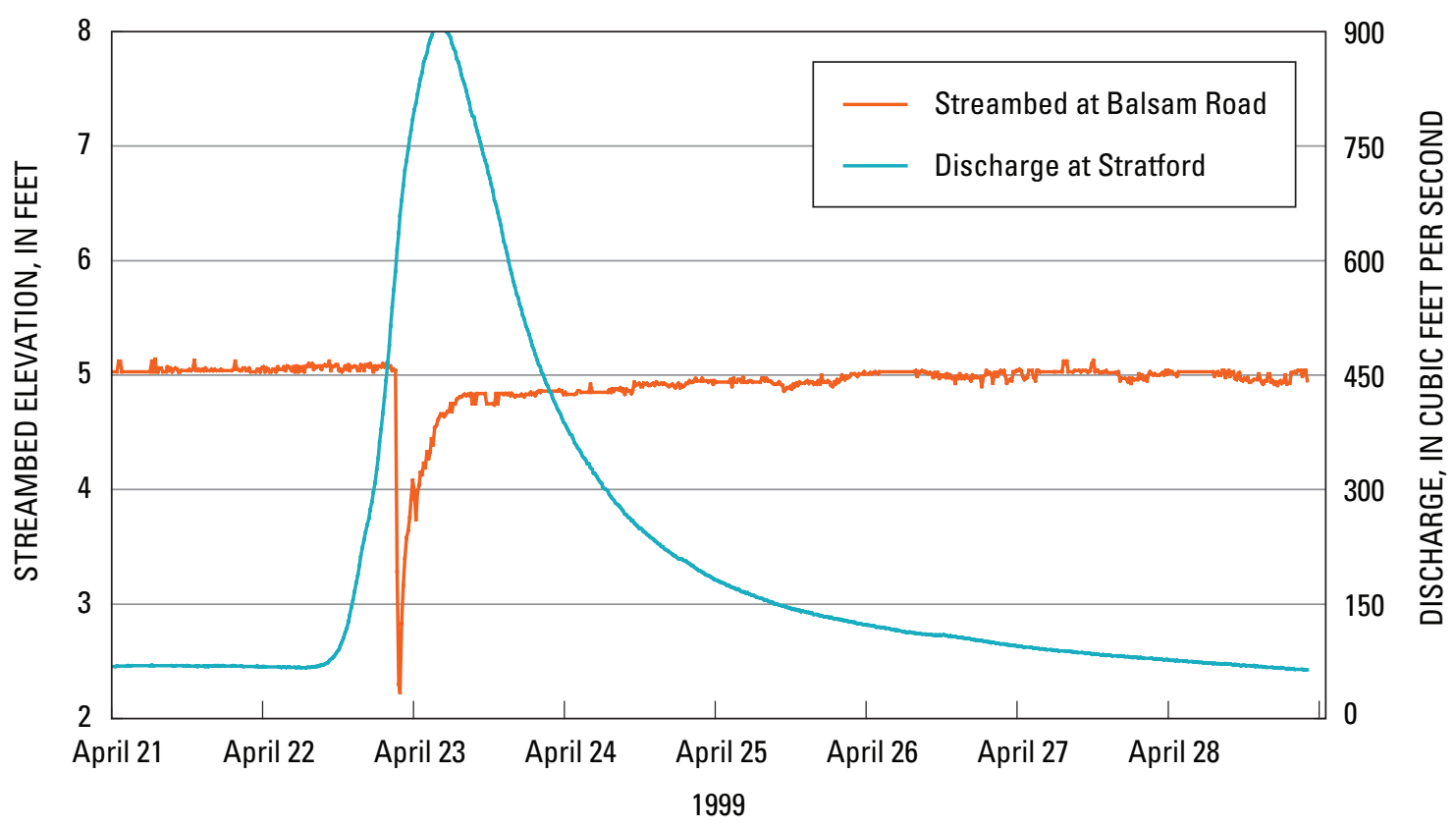

B

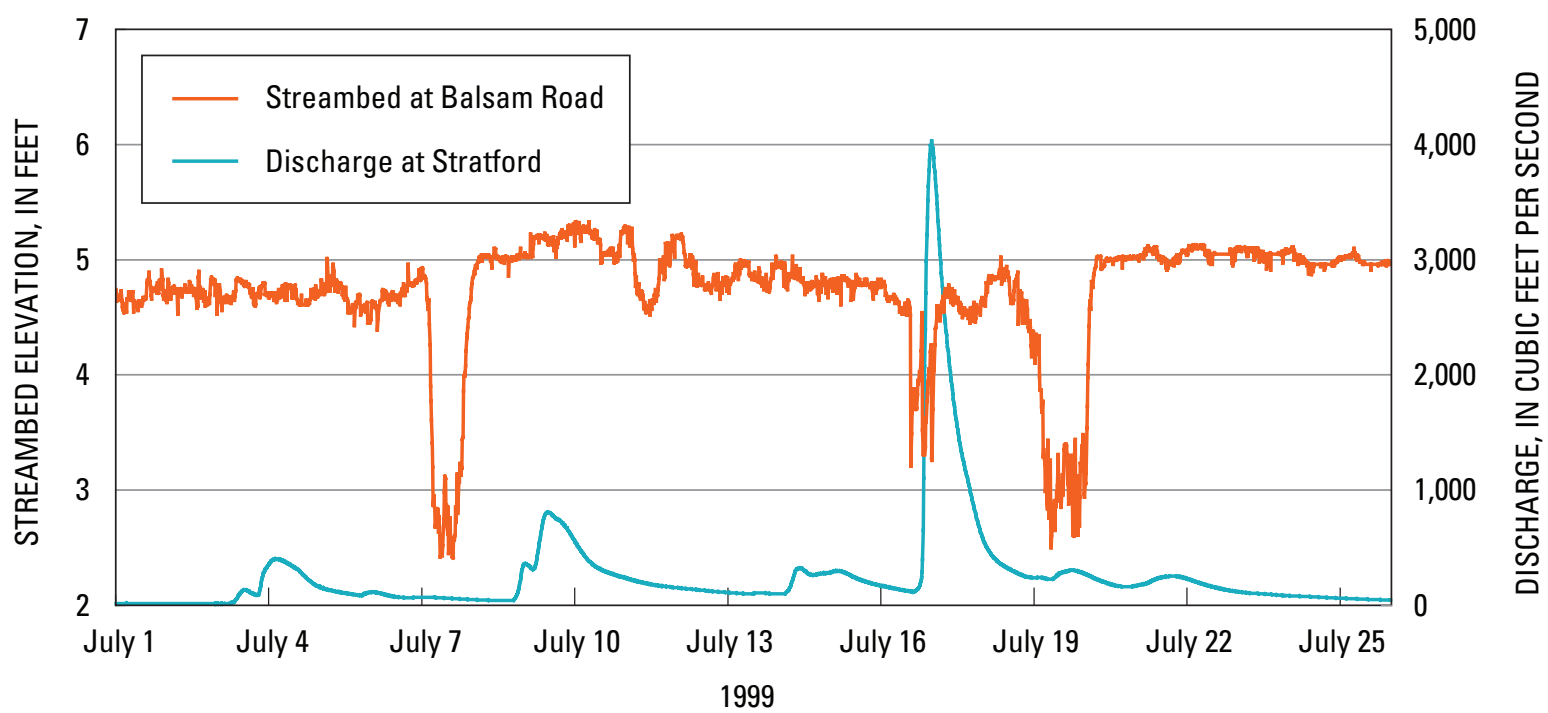

Figure 7. Continuous scour record from the upstream transducer at the Balsam Road bridge over the Big Eau Pleine River for $(\boldsymbol{A})$ a small storm in April, 1999 and $(\boldsymbol{B})$ several flow events in July, 1999. The discharge hydrograph is from the gage at Stratford, $7.7 \mathrm{mi}(12.4 \mathrm{~km})$ upstream of the bridge.

with the flow record at the upstream gage. Because the streamflow gage is upstream of the backwater caused by the Big Eau Pleine reservoir and the Balsam Road bridge is within the influence of the backwater from the reservoir, it is likely that the discharges and associated velocities that occurred at the bridge are substantially different than those at the gage. Without detailed hydraulic modeling it is not possible to estimate the velocities near the pier using the available data. Based on frequency analyses using data through the 2000 water year (Walker and Krug, 2003), all the events monitored were less than the two-year flood. Note that there are significant scour and subsequent filling periods, and that overall there is a slight filling of the channel in the vicinity of the pier.

Selected results for the continuous monitoring at the Wisconsin Highway 35 bridge over Tank Creek are presented in figure 8 . Note that the water-surface elevation, an indication of the discharge and associated velocities, was 


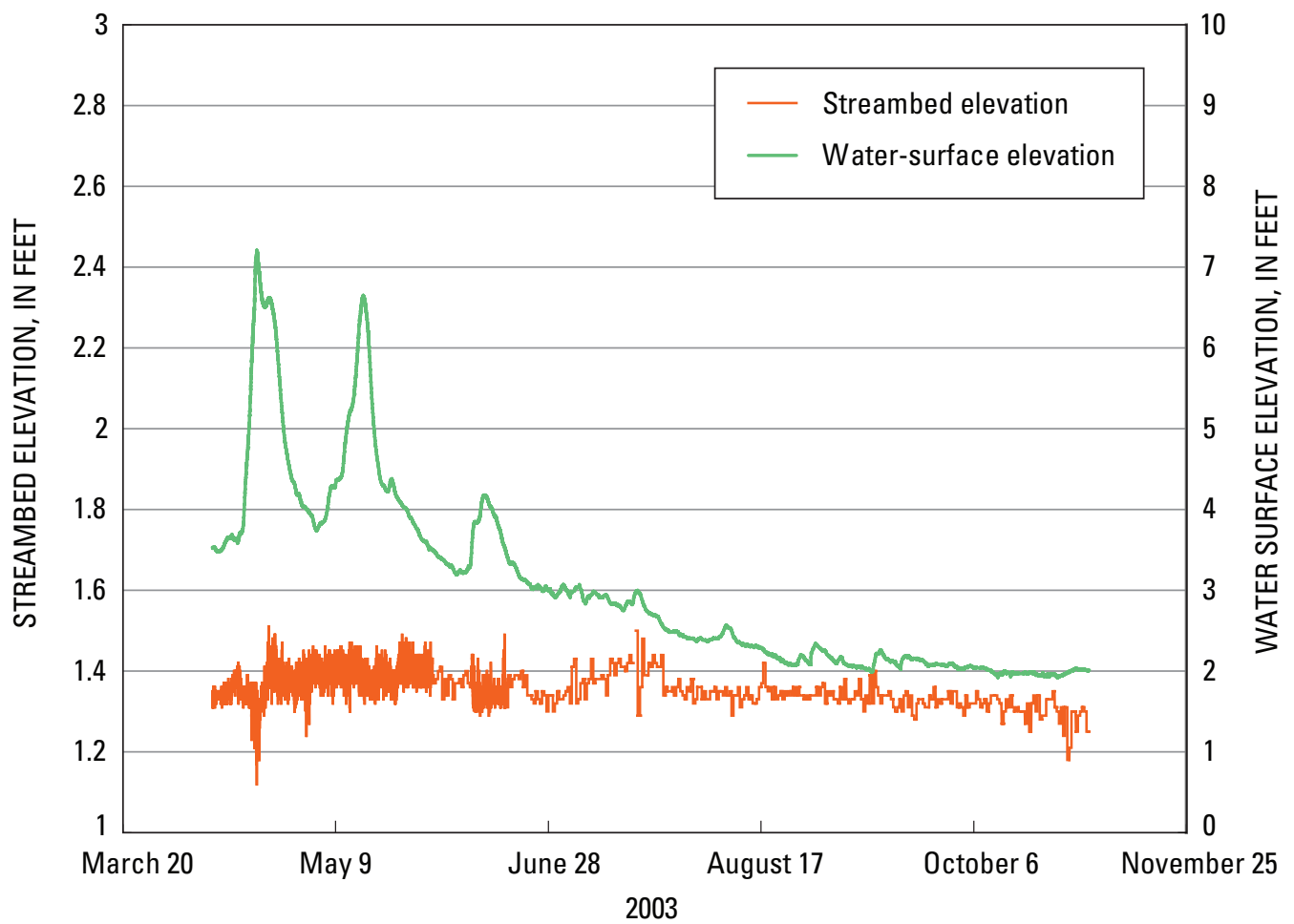

Figure 8. Continuous scour measurements from the upstream transducer at the Wisconsin Highway 35 bridge over Tank Creek.

collected at the site, thus there should be a good association between the hydrograph and the associated change in the streambed. For the period displayed, however, there is very little change in the streambed. This is largely due to the armoring provided by the rip-rap installed at the site prior to installation of the monitoring equipment. Periodic manual inspections of the elevation of the streambed in the vicinity of the upstream pier has confirmed that there has been little net change in the streambed elevation. Note that the "noise" in the signal is a fairly good indication of the uncertainty of the monitoring equipment. For the most part, one could conclude that the measurements recorded by the transducer had an uncertainty of less than $0.1 \mathrm{ft}$ (3 $\mathrm{cm}$ ), which is somewhat less than the accuracy stated in the specifications, but well within limits needed for monitoring streambed scour.

\section{Discussion}

The two data-collection approaches described in this report are quite different, and serve two different types of monitoring objectives. The manual technique using fixed wire-weight gages can be used to document overall long-term changes to the streambed. The method results in reasonably accurate readings but may be affected by the technique used by the observer to lower the weight to the streambed. Because the manual technique is labor intensive, it is less desirable than the automated method for monitoring episodic changes on a short time scale.

The automated technique using an ultrasonic ranging transducer can be used quite effectively to monitor episodic changes to the streambed. Previous work has demonstrated the reliability of the equipment for monitoring streambed changes (Griffin, 1997). Because the data are collected using an electronic datalogger, it is possible to disseminate the data in realtime and alert users of current scour conditions. The observed accuracy of the transducer is somewhat lower than unit specifications, but is still acceptable for observing substantial changes in the streambed. With unattended electronic equipment, it is imperative that periodic check measurements are made throughout the monitoring period. This will document the accuracy of the equipment.

Establishment of the causal nature of scour events requires some indication of the velocities in the vicinity of the scour-monitoring equipment. Direct velocity transducers would provide the best data set for verification of the event. In other cases, estimates of discharge based on a stream gage at or near the site will give a reasonable 
indication of the discharge and associated velocities during an event. The use of a distant stream gage in conditions of backwater, as in the case of the Balsam Road monitoring site, provides little or no information about the discharge at the scour-monitoring site.

There were two transducers installed at the Balsam Road bridge — one on the upstream side and the other on the downstream side of the pier. This type of installation, in a sense, provided some redundancy for the scour monitoring. The downstream transducer was damaged by ice flows during the spring breakup in 1998, and funding was insufficient to repair or replace it. While the upstream transducer continued to function, differences in local scour conditions precluded the use of data from the upstream location as a substitute for the downstream location. In most instances, redundant transducers should be installed at the same side of a pier and be physically separated to prevent damage to both transducers from ice or debris.

Scour cannot be visually detected during a flood and inspection after the flood waters have receded cannot fully determine that a bridge is safe because scour holes generally fill in during the falling stage of a flood. Reliable instrumentation capable of measuring maximum scour depth in real time during flooding conditions provides valuable information that could be used for making decisions regarding bridge closures and schedules for the design and construction of countermeasures.

\section{Pros and Cons}

For the manual technique, advantages include relatively low cost of installation and operation, highly accurate readings, and the ability to effectively document relatively long-term changes in the streambed. Disadvantages include the inability to effectively document episodic changes on a short time scale, and an inability to provide real-time data. For the automated technique, advantages include reasonably accurate measurements of streambed changes, the ability to monitor episodic changes over short time scales, and the ability to provide real-time data. A major obstacle to using this technique is designing a transducer mounting system that is economical, easy to install, and immune to damage from ice or debris. Other disadvantages include relatively high costs for installation and operation, and the need for check measurements to verify operation of the equipment.

\section{Summary}

The U.S. Geological Survey, in cooperation with the Wisconsin Department of Transportation, the Marathon County Highway Department, and the Jefferson County Highway Department, performed routine monitoring of streambed elevations for three bridges. Two monitoring approaches were employed: (1) manual monitoring using relatively simple equipment, and (2) automated monitoring using moderately sophisticated electronic equipment. The results from all three sites demonstrate that both techniques can produce reasonable measurements of streambed elevation. The manual technique has a lower annual operating cost, and is useful for cases where documentation of long-term trends is desired. The automated technique has a higher annual operating cost and is useful for real-time monitoring of episodic events with short time durations. The automated technique would be appropriate for cases where information is needed to make decisions regarding bridge closures and for the design and construction of scour countermeasures. Because the acoustic transducers need to be installed at the upstream side of the bridge piers, it is difficult to design and install an economical mounting system that is immune to damage from ice or debris.

\section{References Cited}

Griffin, M.S., 1997, Use of an acoustic ranging system to monitor sediment deposition and erosion for the protection of an endangered mussel below the Olmsted locks and dam, Illinois: U.S. Dept. of the Interior, U.S. Geological Survey Fact Sheet 127-94, 4 p.

Parsons Brinckerhoff, Quade \& Douglass, Inc., 1997, Scour analysis for Balsam Road bridge over the Big Eau Pleine River, Marathon County, Wisconsin.

Richardson, E.V. and S.R. Davis, 2001, Evaluating scour at bridges, fourth edition, Federal Highway Administration Report FHWA NHI 01-001, HEC-18, Arlington, VA, $378 \mathrm{p}$.

Walker, J.F., and Krug, W.R., 2003, Flood-frequency characteristics of Wisconsin streams: U.S. Geological Survey Water-Resources Investigations Report 03-4250, $37 \mathrm{p}$. 
8 Printed on recycled paper 